\title{
Development of Organometallic Ruthenium(II) Anticancer (RAPTA) Drugs
}

\author{
Wee Han Ang* \\ METTLER TOLEDO Award Winner (Oral Presentation)
}

\begin{abstract}
The systematic development of the RAPTA family of organometallic ruthenium(II) anticancer drugs containing a monodentate 1,3,5-triaza-7-phosphatricyclo-[3.3.1.1]decane (pta) ligand and a $\eta^{6}$-arene ligand is described.
\end{abstract}

Keywords: Anticancer drugs · Antitumour · Chemotherapy · Metallopharmaceuticals · Ruthenium

\section{Introduction}

The discovery by Rosenberg in 1965 that cis-diamminedichloroplatinum(II) (cisplatin) could effectively inhibit tumour growth formation laid the foundation of a new era of anticancer research centred on metallopharmaceuticals. ${ }^{[1]}$ Over the past three decades, cisplatin and other platinum-based anticancer drugs have become some of the most important chemotherapeutic agents in clinical use, often as the first line of treatment in testicular and ovarian cancers. ${ }^{[2,3]}$ However, they are highly toxic and their effectiveness is limited by incidence of drug resistance. ${ }^{[4]}$ This has led to increased interest in developing anticancer drugs based on ruthenium. ${ }^{[5]}$ The rich coordination chemistry of ruthenium means that a diverse range of compound can be readily prepared and tested. ${ }^{[5,6]}$ Importantly, many ruthenium compounds have been found to be less toxic than their platinum counterparts. ${ }^{[6,7]}$ In fact, two ruthenium-based coordination compounds, namely KP1019 and NAMI-A, have successfully completed Phase 1 clinical trials and are scheduled to enter Phase 2 trials in the near future. ${ }^{[8]}$ More recently, there has been strong interest in organometallic

${ }^{\star}$ Correspondence: W. H. Ang

Ecole Polytechnique Fédérale de Lausanne (EPFL)

Institut des Sciences et Ingénierie Chimiques

SB-ISIC-LCOM

$\mathrm{CH}-1015$ Lausanne

Tel.: +41216939864

Fax: + 41616939885

E-Mail: weehan.ang@epfl.ch

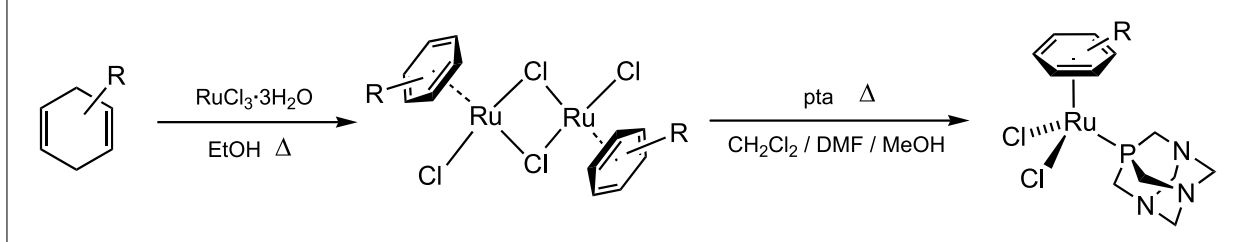

Scheme. General synthesis of RAPTA complexes.

ruthenium complexes as anticancer drug candidates. In particular, the RAPTA series of complexes have been intensively studied and found to exhibit favourable pharmacological and cytotoxic profiles for application as anticancer drugs.

\section{Development of RAPTA Complexes as Anticancer Drugs}

RAPTA comprises a family of organometallic ruthenium(II) complexes with a monodentate 1,3,5-triaza-7-phosphatricyclo-[3.3.1.1]decane (pta) ligand and a $\eta^{6}$ arene ligand. The compounds are readily synthesised in two steps: the first step involves the reaction of $\mathrm{C}_{6}$-dienes, typically derived using Birch reduction of the desired arene, with hydrated $\mathrm{RuCl}_{3}$ to yield dimeric $\left[\left(\eta^{6} \text {-arene }\right) \mathrm{RuCl}_{2}\right]_{2} \cdot{ }^{\left[{ }^{[9]}\right.}$ In the second step, two equiv. of pta are added to $\left[\left(\eta^{6} \text {-arene }\right) \mathrm{RuCl}_{2}\right]_{2}$ in organic solvents to yield the desired RAPTA complex (Scheme). Ligand exchange using the arene-labile complex $\left[\left(\eta^{6}-\right.\right.$ $\left.\left.\mathrm{PhCO}_{2} \mathrm{Et}\right) \mathrm{RuCl}_{2}\right]_{2}$ can also be carried out for arene ligands that cannot be readily reduced via Birch reduction, such as benzocrown ethers. ${ }^{[10]}$ RAPTA compounds are generally air-stable complexes that are soluble in both polar organic solvents and water. ${ }^{[11]} \mathrm{A}$ large number of RAPTA complexes of the general formula (arene)Ru(pta) $\mathrm{X}_{2}$ where $\mathrm{X}$
$=\mathrm{Cl}, \mathrm{Br}, \mathrm{I}, \mathrm{SCN}$ or bridging carboxylate ligands have so far been synthesised and studied (Fig. 1). In addition, RAPTA analogues containing other organometallic fragments, namely $\left[\left(\eta^{5}-\mathrm{C}_{5} \mathrm{H}_{5}\right) \mathrm{Ru}\right], \quad\left[\left(\eta^{5}-\mathrm{C}_{5} \mathrm{Me}_{5}\right) \mathrm{Ru}\right]$, $\left[\left(\eta^{5}-\mathrm{C}_{5} \mathrm{Me}_{5}\right) \mathrm{Rh}\right]$ and $\left[\left(\eta^{6}\right.\right.$-cymene $\left.) \mathrm{Os}\right]$ have also been prepared. ${ }^{[12]}$

The cytotoxicity of RAPTA complexes in vitro (TS/A, HBL-100) are generally low in comparison to platinum-based compounds, such as cisplatin. ${ }^{[13]}$ However, the lead RAPTA complexes, namely RAPTA-C (1) (Fig. 2), RAPTA-B (2) and RAPTA-T (3), exhibit selective cytotoxicity towards the TS/A tumourgenic murine cell line as opposed to the HBL-100 non-tumourgenic mammalian cell line, providing an indication that complexes are benign towards healthy cells. This is important since high systemic toxicity is associated with the drastic side-effects of cisplatin and related drugs and limits the amount of drug that can be administered. Similarly, NAMI-A, which is undergoing clinical trials as an antimetastatic agent, is non-cytotoxic to both TS/A and HBL-100 cell lines up to 1 $\mathrm{mM}$ concentration. ${ }^{[14]}$

From a structure-activity relationship standpoint, both the pta and aromatic fragments affect the in vitro activity differently. The pta fragment appears to be important for determining the selectivity of the complexes. For example, RAPTA-C (1) and RAPTA-T (3) are highly selective towards 


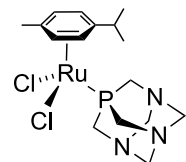

RAPTA-C 1<smiles>CCOc1ccccc1P(Cl)(Cl)(Cl)C12CN3CN(CN(C3)C1)C2</smiles>

RAPTA-CE 5

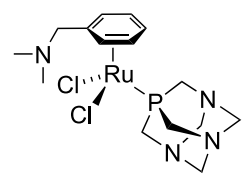

RAPTA-N1 8

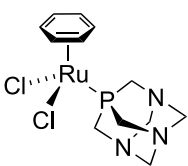

RAPTA-B 2

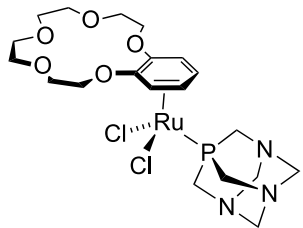

RAPTA-BC 6
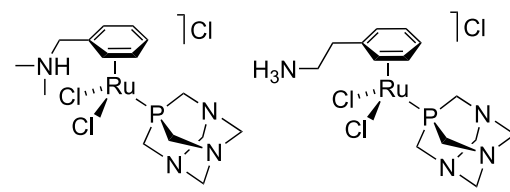

RAPTA-BI 7
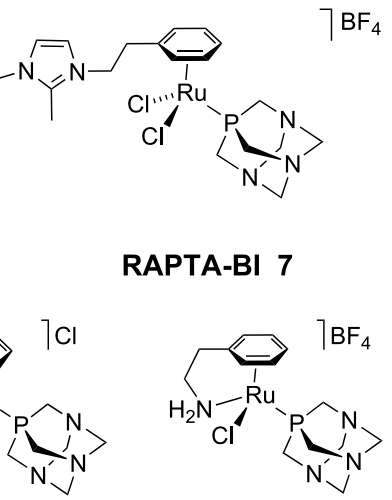

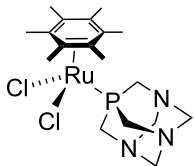

RAPTA-H 4

$F_{4}$

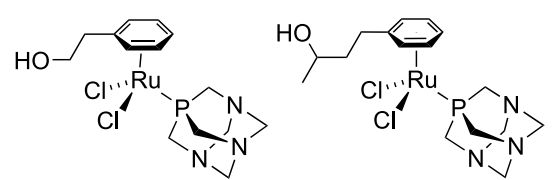

RAPTA-01 12

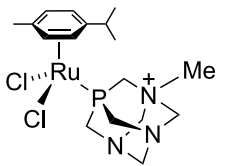

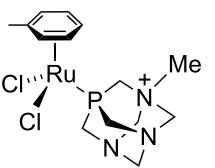

$\operatorname{RAPTA}\left(\mathrm{Me}^{+}\right)-\mathrm{C} 16$
RAPTA-N2 9

RAPTA-N3 10

RAPTA-02 13

$$
\underbrace{\mathrm{N}}_{\mathrm{O}^{-1} \mathrm{~N}^{\mathrm{N}}}
$$

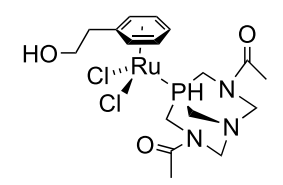

RAPTA-N4 11

\section{RAPTA(Ac)-N3 $14 \quad$ RAPTA(AC)-01 15}

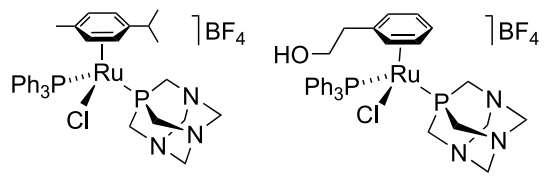

RAPTA[tpp]-C 18 RAPTA[tpp]-01 19

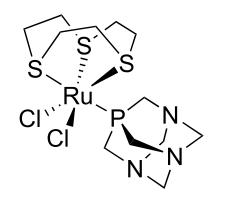

RAPTA-S $_{3} 20$

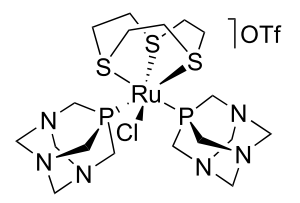

RAPTA[pta]-S 21

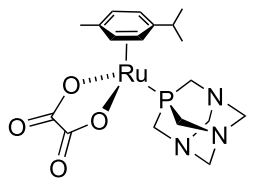

OxaloRAPTA-C 22

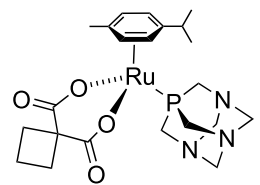

23

Fig. 1. Selected examples of RAPTA complexes

cancer cell lines whereas RAPTA $\left(\mathrm{Me}^{+}\right)$C (16) and RAPTA $\left(\mathrm{Me}^{+}\right)-\mathrm{T}$ (17), which have a pta- $\mathrm{Me}^{+}$ligand in place of pta, do not exhibit significant selectivity. ${ }^{[13,15]}$ The aromatic fragment on the other hand was found to be not an essential feature for in vitro activity and could even be replaced by another face-capping ligand with low steric demand. For example, RAPTA-S3 (20) with the [9]ane $S_{3}$ ligand is only slightly less selective and cytotoxic compared to RAPTA-C (1).[16] Therefore, the arene ligand could be functionalised accordingly to impart desirable attributes. In particular, RAPTA complexes with H-bonding groups attached to the arene ring (complexes 8-15) have been found to be more reactive than RAPTA compounds 1-3 with respect to binding with single strand DNA, although their cytotoxicity were not improved in $\mathrm{vi}$ tro due to reduced uptake. ${ }^{[17]}$

RAPTA complexes 1-3 have also been studied for potential antimetastatic activity on CBA mice with MCa mammary carcinoma. ${ }^{[13]}$ In vivo experiments found the RAPTA complexes to be well tolerated by mice at very high doses and a low sustained treatment regime of RAPTA-C at $4 \times 100$ $\mathrm{mg} / \mathrm{kg} /$ day resulted in significant reduction in both lung metastases weight and number in treated mice whilst leaving the primarily tumour unaffected. Although the RAPTA complexes displayed marginally less antimetastatic activity than NAMI-A, it is less toxic to mice and can potentially be administered at higher dosage.

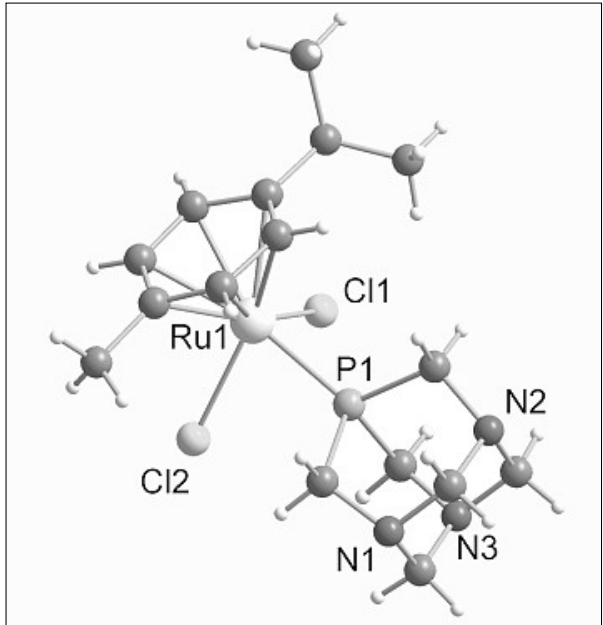

Fig. 2. Ball and stick representation of RAPTA-C (1)

\section{Enhancing the in vitro Activity of RAPTA}

Like other transition metal-based drugs including cisplatin, RAPTA complexes are prone to hydrolysis in aqueous media and would have to be administered in saline to suppress the cleavage of the chloride ligands. Chelating carboxylate ligands, namely oxalate, glycolate and 1,1-cyclobutane-dicarboxylate ligands have been used to improve the stability and solubility of the platinum complexes in water.[2] With a view to develop drugs that could resist hydrolysis in aqueous media, RAPTA complexes 22 and 23, bearing chelating carboxylate ligands in place of the two chloride ligands (Fig. 3 ), have been developed. ${ }^{[18]}$ The new complexes are kinetically more stable than $\mathbf{1}$, and essentially, retain the carboxylate ligand in aqueous solution. Preliminary investigations show that these derivatives exhibit the same order of cytotoxicity in vitro as $\mathbf{1}$ and similar binding characteristics with DNA models, hence proving to be a possible replacement for RAPTA-C for clinical studies. [18]

Another strategy that could potentially enhance the efficacy of the complexes is to build specific functionality onto the RAPTA molecule, so that they have multiple modes of activity. We previously showed that such a strategy could be applied to Pt(IV) drugs. ${ }^{[19]}$ RAPTA complexes designed to inhibit glutathione-S-transferases (GST), a cytosolic detoxification enzyme associated with drug resistance, have been developed.[20] GST catalyses the conjugation of intracellular xenobiotics with glutathione, which is then expelled from cells via the GS-export pump. By incorporating ethacrynic acid, a known GST-inhibitor, onto their arene rings, RAPTA complexes 24 and 25 (Fig. 4) were found to retain the same order of GST inhibition activity as ethacrynic acid. At the same time, the new complexes have higher cytotoxic activity (A2780, A2780cisR ovarian carcinoma) than either ethacrynic acid or RAPTA-C (1). 


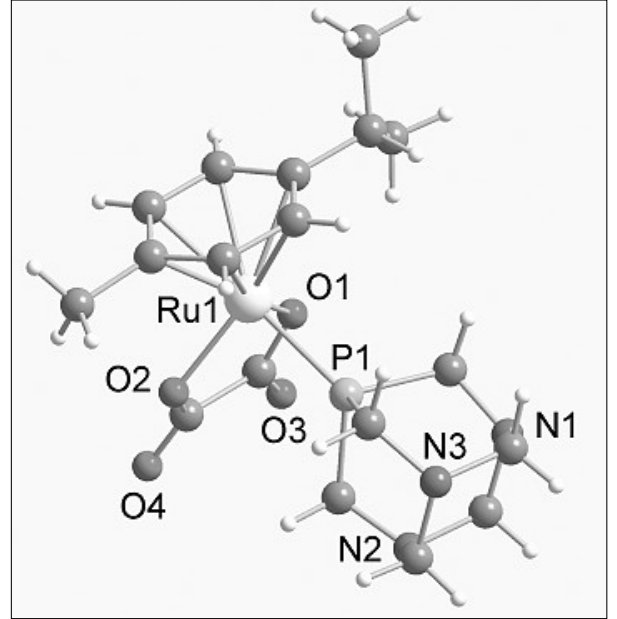

Fig. 3. Ball and stick representation of oxaloRAPTA-C (22)

\section{Summary and Outlook}

The high selectivity, low cytotoxicity and antimetastatic properties suggest that the mechanism of activity of RAPTA complexes is different from classical anticancer agents, such as cisplatin, that target DNA. Early on, specific protein binding interactions were detected with RAPTA-C, which could be the basis of new therapeutic targets beyond DNA. ${ }^{[21]}$ In line with the goal to construct RAPTA complexes that target specific protein molecules, better analytical methods are also being developed, with the objective of identifying drug-protein binding sites, to elucidate the drug mechanism. [21-23] One of these methods exploits highly sensitive laser-abalation ICP-MS in conjunction with conventional proteomic techniques to detect drug-protein interactions of non-endogenous transitional metalbased drugs in complex mixtures. ${ }^{[21,22]}$ This technique has already been demonstrated using treated human plasma samples and cell lysates. The ultimate goal is to create a map of drug-protein interactions in the proteome of a cancer cell line after treatment with ruthenium drugs. By identifying areas in the proteome on which ruthenium drugs could target, a more rational way of designing non-classical ruthenium drugs could then be developed. ${ }^{[5]}$
The development of anticancer drugs based on the RAPTA model remains an area of considerable potential. The range of possible functional groups that could be incorporated into the RAPTA template is diverse and offers great scope for further enhancement. Extending from RAPTA, investigations into structurally similar organometallic ruthenium(II) complexes containing imidazolium ligands have also begun. ${ }^{[24]}$ Given the limited number of platinum-based drugs entering clinical use since the discovery of cisplatin, research into this area can be expected to intensify.

\section{Acknowledgements}

The author would like to thank Prof. Paul Dyson (EPFL) for his mentorship and supervision, Dr. Lucienne Juillerat-Jeanneret (CHUV) for her invaluable advice and guidance, and $\mathrm{Ms} \mathrm{Ho} \mathrm{Li}-$ Ching (Columbia University) for her unwavering support. Financial support from the Roche Research Foundation is gratefully acknowledged.

\section{Received: November 24, 2006}

[1] B. Rosenberg, L. Vancamp, J. E. Trosko, V. H. Mansour, Nature 1969, 222, 385.

[2] T. Boulikas, M. Vougiouka, Oncol. Rep. 2003, 10, 1663.

[3] A. Pasini, F. Zunino Angew. Chem., Int. Ed. Engl. 1987, 26, 615.

[4] E. Wong, C. M. Giandomenico, Chem. Rev 1999, 99, 2451; M. Galanski, M. A. Jakupec, B. K. Keppler, Curr. Med. Chem. 2005, 12, 2075.

[5] W. H. Ang, P. J. Dyson, Eur. J. Inorg. Chem. 2006, 4003.

[6] C. S. Allardyce, A. Dorcier, C. Scolaro, P. J. Dyson, Appl. Organomet. Chem. 2005, 19, 1; C. S. Allardyce, P. J. Dyson, J. Cluster Sci. 2001, 12, 563; P. J. Dyson, G. Sava, Dalton Trans. 2006, 1929.

[7] C. S. Allardyce, P. J. Dyson, Platinum Metals Rev. 2001, 45, 62; M. Galanski, V. B. Arion, M. A. Jakupec, B. K. Keppler, Curr. Pharm. Des. 2003, 9, 2078; I. Kostova, Curr. Med. Chem. 2006, 13, 1085.

[8] C. G. Hartinger, S. Zorbas-Seifried, M. A. Jakupec, B. Kynast, H. Zorbas, B. K. Keppler, J. Inorg. Biochem. 2006, 100, 891; J. M. Rademaker-Lakhai, D. Van Den Bongard, D. Pluim, J. H. Beijnen, J. H. M. Schellens, Clin. Cancer Res. 2004, 10, 3717; M. A. Jakupec, V. B. Arion, S. Kapitza, E. Reis-

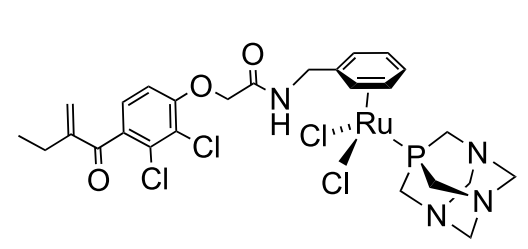

24

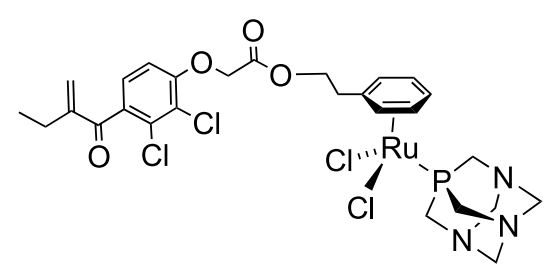

25

Fig. 4. RAPTA complexes designed to defeat GST-mediated drug resistance

ner, A. Eichinger, M. Pongratz, B. Marian, N. Graf v. Keyserlingk, B. K. Keppler, Int. J. Clin. Pharmacol. Ther. 2005, 43, 595; I. Khailaila, A. Bergamo, F. Bussy, G. Sava, P. J. Dyson, Int. J. Oncol. 2006, 29, 261.

[9] M. A. Bennett, A. K. Smith, Dalton Trans. 1974, 233.

[10] T. J. Geldbach, M. R. H. Brown, R. Scopelliti, P. J. Dyson, J. Organomet. Chem. 2005, 690, 5055.

[11] A. D. Phillips, L. Gonsalvi, A. Rornerosa, F. Vizza, M. Peruzzini, Coord. Chem. Rev. 2004, 248, 955.

[12] D. N. Akbayeva, L. Gonsalvi, W. Oberhauser, M. Peruzzini, F. Vizza, P. Bruggeller, A. Romerosa, G. Sava, A. Bergamo, Chem. Comm. 2003, 264; A. Dorcier, W. H. Ang, S. Bolaño, L. Gonsalvi, L. Juillerat-Jeannerat, G. Laurenczy, M. Peruzzini, A. D. Phillips, F. Zanobini, P. J. Dyson, Organometallics 2006, 25, 4090.

[13] C. Scolaro, A. Bergamo, L. Brescacin, R. Delfino, M. Cocchietto, G. Laurenczy, T. J. Geldbach, G. Sava, P. J. Dyson, J. Med. Chem. 2005, 48, 4161.

[14] A. Bergamo, G. Stocco, B. Gava, M. Cocchietto, E. Alessio, B. Serli, E. Iengo, G. Sava, J. Pharmacol. Exp. Ther. 2003, 305, 725; S. Zorzet, A. Bergamo, M. Cocchietto, A. Sorc, B. Gava, E. Alessio, E. Iengo, G. Sava, J. Pharmacol. Exp. Ther. 2000, 295, 927.

[15] A. Dorcier, P. J. Dyson, C. Gossens, U. Rothlisberger, R. Scopelliti, I. Tavernelli, Organometallics 2005, 24, 2114.

[16] B. Serli, E. Zangrando, T. Gianferrara, C. Scolaro, P.J. Dyson, A. Bergamo, E. Alessio, Eur. J. Inorg. Chem. 2005, 3423.

[17] C. Scolaro, T. J. Geldbach, S. Rochat, A. Dorcier, C. Gossens, A. Bergamo, M. Cocchietto, I. Tavernelli, G. Sava, U. Rothlisberger, P. J. Dyson, Organometallics 2006, $25,756$.

[18] W. H. Ang, E. Daldini, C. Scolaro, R. Scopelliti, L. Juillerat-Jeannerat, P. J. Dyson, Inorg. Chem. 2006, 45, 9006.

[19] W. H. Ang, I. Khalaila, C. S. Allardyce, L. Juillerat-Jeanneret, P. J. Dyson, J. Am. Chem. Soc. 2005, 127, 1382; W. H. Ang, S. Pilet, R. Scopelliti, F. Bussy, L. JuilleratJeanneret, P. J. Dyson, J. Med. Chem. 2005, $48,8060$.

[20] W. H. Ang, P. J. Dyson, unpublished results.

[21] C. S. Allardyce, P. J. Dyson, D. J. Ellis, P. A. Salter, R. Scopelliti, J. Organomet. Chem. 2003, 668, 35.

[22] C. S. Allardyce, P. J. Dyson, F. R. AbouShakra, H. Birtwistle, J. Coffey, Chem. Comm. 2001, 2708.

[23] C. S. Allardyce, P. J. Dyson, J. Coffey, N. Johnson, Rapid Commun. Mass Spectrom. 2002, 16, 933; I. Khalaila, C. S. Allardyce, C. S. Verma, P. J. Dyson, ChemBioChem 2005, 6, 1788.

[24] C. A. Vock, C. Scolaro, A. D. Phillips, R. Scopelliti, G. Sava, P. J. Dyson, J. Med. Chem. 2006, 49, 5552. 